University of Nebraska - Lincoln

DigitalCommons@University of Nebraska - Lincoln

$12-1967$

\title{
Observations on the Reproductive Behavior of the Black Bullhead (Ictalurus melas)
}

Charles R. Wallace

University of Nebraska - Lincoln

Follow this and additional works at: https://digitalcommons.unl.edu/bioscifacpub

Part of the Life Sciences Commons

Wallace, Charles R., "Observations on the Reproductive Behavior of the Black Bullhead (Ictalurus melas)" (1967). Faculty Publications in the Biological Sciences. 50.

https://digitalcommons.unl.edu/bioscifacpub/50

This Article is brought to you for free and open access by the Papers in the Biological Sciences at DigitalCommons@University of Nebraska - Lincoln. It has been accepted for inclusion in Faculty Publications in the Biological Sciences by an authorized administrator of DigitalCommons@University of Nebraska - Lincoln. 
Made in United States of America

Reprinted from CopeIA, 1967, No. 4, December 8

pp. 852-853

OBSERVATIONS ON THE REPRODUCTIVE BEHAVIOR OF THE BLACK BULLHEAD (ICTALURUS MELAS).-Two pairs of black bullheads, Ictalurus melas (Rafinesque), were observed spawning out of season in two 90-gal laboratory aquaria after the females had received injections of finely ground acetone-dried carp pituitaries. These fish had been collected in August 1966 and were maintained in the laboratory through the winter in a 75-gal aquarium at an approximate room temperature of $20^{\circ}-25^{\circ} \mathrm{C}$.

The injections of $4.8 \mathrm{mg} /$ fish of ground acetone-dried carp pituitaries mixed with 37,000 units of penicillin-G and two $\mathrm{ml}$ of distilled water were begun on 11 February 1967 and continued twice weekly $(15,18,22$ Feb., and 1 Mar.) until spawning took place on 3 March 1967. The methods recommended by Clemens and Sneed (1960:3) for collection, preservation, and intraperitoneal injection of fish pituitaries were followed. The carp from which the pituitaries were obtained were not classified as to sex, state of sexual maturity, and ripeness. These carp were collected during January 1967 and weighed between three and six lb. They were assumed to be mature but not ripe.

The female black bullheads were kept individually in 15-gal aquaria at $23^{\circ} \mathrm{C}$ from the time of the first injection until the next to last injection. During this period the fish were fed a daily diet of Tenebrio larva, supplemented with small chunks of liver every third day. After the last injection each female was placed in a 90-gal aquarium with a male of similar size. The female and male of one pair weighed 266 and $314 \mathrm{~g}$, respectively, and the female and male of the other pair weighed 190 and $234 \mathrm{~g}$, respectively. The males had been removed from the 75 gal aquarium and placed in the 90-gal aquaria several weeks prior to the start of the injection period. The water temperature in the 90-gal aquaria was $23^{\circ} \mathrm{C}$. There was no attempt to control the photoperiod. The fish were exposed to light from the ceiling 
lights of the laboratory. These lights are normally on from 8:00 AM until 10:00 PM.

Both pairs of black bullheads spawned two days after the fifth injection. One pair began spawning about 10:00 AM, and the other pair began about 1:30 PM. The following description refers to the behavior of both pairs because no differences were observed between their behaviors. The reproductive behavior of the black bullhead is similar to that described by Breder (1935) for Ictalurus nebulosus, and by Clemens and Sneed (1957) for Ictalurus punctatus. The female excavated a nest area by removing small gravel to form a hollow depression near one end of the aquarium. The excavation was carried out by downward fanning of the pelvic fins, side-to-side fanning of the anal fin, and pushing of small pebbles toward the periphery of the depression with the snout. The male was nearby, but did not assist in the excavation.

As the nest neared completion both fish began paying more attention to each other. When the male swam over the nest the female butted him in the abdominal area as if to push him from the nest. During this time the male and female were always close, usually touching each other with their barbels.

The spawning act resembled in some aspects the spawning reflex that Clemens and Sneed (1957) described for the channel catfish. While the male and female were oriented in opposite directions, the male twisted his caudal fin to one side toward the female so that it was over her head and eyes. The first few attempts lasted only briefly and were obviously unsuccessful. After several such actions, the male held the female in this way for a period of several seconds. The male's caudal fin was more tightly twisted over the female's head, and the ventral part of his body anterior to the twisted portion was arched almost in a $45^{\circ}$ angle toward the abdomen of the female. The female's body was not arched, but her caudal fin was bent slightly toward and almost over the male's head. The male's mouth was widely opened as if "yawning," and his head was bent slightly downward. This "embrace" posture lasted for approximately five sec, and appeared to quiet the female. The first three times the embrace occurred no eggs were deposited and when they separated the fish continued to swim about the nest as before.
During the fourth embrace the female quivered for about one sec and eggs were deposited. The male remained perfectly still with its mouth wide open. His head was bent downward, as if he were straining violently. The female's quivering apparently caused her to jerk to one side, thus separating the fish by a distance of one or two inches. After the female stopped quivering both fish moved apart and lay still for about one min on the bottom of the aquarium. They then began swimming as before; the female passing back and forth over the center of the nest fanning the eggs with pelvic and anal fins, and butting the male's abdomen when he swam near the eggs.

Spawning occurred five times within one hr. After the first two spawnings the number of embraces preceding egg deposition decreased. The number of eggs deposited each time could not be determined, and it was also impossible to determine exactly when the male fertilized the eggs. Samples of eggs preserved $21 \mathrm{hr}$ after spawning had developed to the late gastrula stage.

The female fanned and guarded the eggs during the first day, but on the second and third days after spawning the male guarded the nest. During the night between the third and fourth day after spawning the eggs disappeared-apparently eaten by the parents.

I express my sincere thanks to the $\mathrm{Ne}$ braska Game, Forestation, and Parks Commission for financial support, and the Department of Zoology and Physiology of the University of Nebraska where this work was carried out. This is a Contribution of Federal Aid in Fish Restoration, Project F-4-R, Nebraska.

\section{Literature Cited}

Breder, C. M., JR. 1935 . The reproductive habits of the common catfish, Ameiurus nebulosus (Le Sueur), with a discussion of their significance in ontogeny and phylogeny. Zoologica, N. Y., 19:143-185.

Clesmens, H. P. ANd K. E. SNeed. 1957. The spawning behavior of the channel catfish Ictalurus punctatus. U. S. Fish Wildl. Serv. Spec. Sci. Rep.-Fish. No. 219, 11 pp.

AND 1960. Use of fish pituitaries to induce spawning in channel catfish. Ibid. No. 329, 12 pp.

Charles R. Wallace, Department of Zoology and Physiology, University of Nebraska, Lincoln, Nebraska 68508. 